\title{
PENGARUH PELABUHAN TERHADAP PERTUMBUHAN EKONOMI DI PULAU SULAWESI
}

\author{
Abdul Rakhman ${ }^{1),}$ Neneng ${ }^{2),}$ Asni Saputri ${ }^{3)}$. Amiruddin Akbar Fisu ${ }^{4)}$ \\ 1,2,3) Mahasiswa Program Studi Teknik Sipil, Universitas Andi Djemma, Palopo \\ 4) Dosen Fakultas Teknik, Universitas Andi Djemma Palopo \\ 1) abdulrakhman031@gmail.com $^{2)}{ }_{\text {neneghaswa@gmail.com }}^{3)}$ asnisaputri33@gmail.com \\ 4) amiruddinakbarfisu07@,gmail.com
}

\begin{abstract}
Abstrak
Salah satu tujuan utama pembangunan dan pengembangan pelabuhan adalah untuk memicu pertumbuhan perekonomian suatu wilayah atau daerah. Pulau Sulawesi merupakan daerah dengan pertumbuhan perekonomian yang cukup pesat dan sekaligus pulau yang memiliki begitu banyak pelabuhan. Penelitian ini bertujuan untuk melihat pengaruh keberadaan pelabuhan terhadap perekonomian di Pulau Sulawesi. Variabel utama yang digunakan adalah PDRB dan pertumbuhan ekonomi pada tiap kabupaten/kota di Pulau Sulawesi. Teknik analisis yang digunakan adalah regresi linier dengan menggunakan pembobotan/skoring pada tip jenis pelabuhan. Hasil penelitian menunjukkan bahwa terdapat pengaruh kecil namun cukup signifikan antara pelabuhan dan perekonomian di Pulau Sulawesi, yaitu 1,11\%. Namun ketika variable pelabuhan kategori pengumpan lokal di keluarkan dari model, pengaruh pelabuhan terhadap perekonomian meningkat drastis menjadi $20,4 \%$.
\end{abstract}

Kata kunci: Pelabuhan, PDRB, Perekonomian, Pulau Sulawesi

\section{PENDAHULUAN}

Latar Belakang

Kondisi geografis Indonesia dikenal sebagai Negara Kepulauan. Sebagai Negara Kepulauan Transportasi laut menjadi sarana yang mendominasi dan penting guna mempermudah hubungan antar pulau di seluruh wilayah Indonesia. Hubungan sosial antar warga negara dan jalur distribusi juga dihubungkan oleh sarana transportasi laut. Sarana transportasi laut membawa dampak positif bagi negara Indonesia, khususnya pada daerah-daerah yang memiliki pelabuhan. Pelabuhan yang merupakan simpul transportasi laut menjadi fasilitas penghubung dengan daerah lain untuk melakukan aktivitas perdagangan. Pelabuhan memiliki peran penting dalam perekonomian Negara untuk menciptakan pertumbuhan ekonomi. Menurut Pasal 1 angka 1 Peraturan Meteri Perhubungan No. 51 Tahun 2015 Tentang Penyelenggaraan Pelabuhan laut, pelabuhan adalah tempat yang terdiri dari daratan dan perairan disekitarnya dengan batas tertentu sebagai tempat kegiatan pemerintahan dan kegiatan ekonomi yang dipergunakan sebagai tempat kapal bersandar, berlabuh, naik turun penumpang dan/atau bongkar muat barang yang dilengkapi dengan fasilitas keselamatan pelayaran dan kegiatan penunjang pelabuhan serta sebagai tempat perpindahan intra dan antar moda transportasi. Atas dasar inilah dapat dikatakan bahwa pelabuhan sebagai salah satu infrastruktur transportasi, dapat membangkitkan kegiatan perekonomian suatu wilayah karena merupakan bagian dari mata rantai dari sistem transportasi maupun logistik.

Sementara itu Pelabuhan sebagai tempat kegiatan pemerintahan dan pengusahaan, yang terdiri atas Pelabuhan Utama, Pelabuhan Pengumpul, Pelabuhan Pengumpan, sebagaimana 
disebutkan dalam Peraturan Meteri Perhubungan No. 51 Tahun 2015 Tentang Penyelenggaraan Pelabuhan laut bahwa Pelabuhan Utama adalah pelabuhan yang fungsi pokoknya melayani kegiatan angkutan laut dalam negeri dan internasional, alih muat angkutan laut dalam negeri dan internasional dalam jumlah besar, dan sebagai tempat asal tujuan penumpang dan/atau barang, serta angkutan penyeberangan dengan jangkauan pelayanan antar provinsi. Pelabuhan Pengumpul adalah pelabuhan yang fungsi pokoknya melayani kegiatan angkutan laut dalam negeri, alih muat angkutan laut dalam negeri dalam jumlah menengah, dan sebagai tempat asal tujuan penumpang dan/atau barang, serta angkutan penyeberangan dengan jangkauan pelayanan antar provinsi. Pelabuhan Pengumpan adalah pelabuhan yang fungsi pokoknya melayani kegiatan angkutan laut dalam negeri, alih muat angkutan laut dalam negeri dalam jumlah terbatas, merupakan pengumpan bagi pelabuhan utama dan pelabuhan pengumpul, dan sebagai tempat asal tujuan penumpang dan/atau barang, serta angkutan penyeberangan dengan jangkauan pelayanan dalam provinsi. Pembangunan atau pengembangan sarana transportasi juga dapat menimbulkan dampak positif terhadap suatu wilayah (Fisu, 2018). Transportasi sangat terkait dengan aksesibilitas, dimana aksesibilitas merupakan faktor yang sangat menentukan organisasi ruang di kawasan perkotaan. Menurut Fisu (2016), salah satu ciri kota atau zona yang dapat mempengaruhi pemilihan moda transportasi adalah kepadatan penduduk dan jarak dari pusat kota. Peningkatan aksesibilitas dan penggunaan lahan adalah proses yang saling terkait (Fisu, 2019). Kegiatan pembangunan dan pengembangan infrastruktur perlu pengkajian mendalam dari berbagai sisi, termasuk aspek daya dukung lahan dan aspek tata ruang (Fisu, 2019). Di sisi lain pertumbuhan aktivitas ekonomi akan mempengaruhi permintaan terhadap transportasi yang lebih banyak (Fisu, 2019), pembangunan atau pengembangan sarana transportasi juga dapat menimbulkan dampak positif terhadap suatu wilayah (Fisu, 2018). Salah satu contohnya adalah pelabuhan dapat mendukung aktifitas industri, baik itu industri perikanan maupun non perikanan (Fisu, Didiharyono \& Bakhtiar, 2020) yang dapat memicu pertumbuhan ekonomi. Hal ini didukung oleh Marsus dkk (2020) yang menyatakan bahwa pembangunan sarana transportasi dapat memicu pertumbuhan ekonomi suatu wilayah.

Peran pelabuhan terhadap pembangunan ekonomi semakin besar seiring dengan semakin penting-nya pelabuhan dalam aktivitas logistik, khususnya transportasi intermoda atau multimoda (Mandasari dkk, 2017). Selain itu, pelabuhan biasanya juga menjadi tempat bermulanya suatu kota atau peradaban dan tidak sedikit terdapat bangunan cagar budaya dan bangunan colonial pada wilayah perkotaan (Nurhijrah \& Fisu, 2019), khususnya kota pelabuhan. salah satu Peran penting dan strategis suatu pelabuhan dalam aktivitasnya sangat besar disumbangkan bagi pertumbuhan industri, ekonomi dan perdagangan serta merupakan bidang usaha yang memberikan kontribusi bagi pembangunan ekonomi nasional (Elfrida, 2017). Salah satu tujuan suatu negara adalah untuk meningkatkan pertumbuhan ekonominya. Salah satu ukuran pertumbuhan ekonomi adalah pendapatan nasional. Pendapatan nasional suatu Negara dapat menunjukkan seberapa besar aktivitas perekonomian secara keseluruhan. Konsep pendapatan nasional adalah ukuran yang paling sering dipakai sebagai indikator pertumbuhan ekonomi namun bukan satu-satunya indikator pertumbuhan ekonomi. Pertumbuhan ekonomi adalah sebuah proses, bukan merupakan suatu gambaran ekonomi pada suatu periode tertentu, ada 
perkembangan atau perubahan dan penggunaan waktu. Masalah pertumbuhan ekonomi di suatu daerah tergantung pada banyak faktor, salah satunya adalah kebijakan pemerintah itu sendiri. Kebijakan pemerintah tersebut harus dikenali dan diidentifikasi secara tepat supaya pertumbuhan ekonomi dapat tercapai di suatu daerah. Pertumbuhan ekonomi suatu daerah dapat diukur dengan melihat laju pertumbuhan PDRB atas dasar harga berlaku.

Jasa transportasi memiliki peran penting dalam menunjang kelancaran perekonomian nasional khususnya pelabuhan. Pentingya jasa transportasi tercermin pada sarana dalam menunjang distribusi sehingga dapat memperlancar arus barang.

Salah satu Pulau di Indonesia dengan gugusan pulau yang terbentang di sekitarnya ialah Pulau Sulawesi. Pulau Sulawesi adalah wilayah pedalaman berupa pegunungan yang tinggi dengan sebagian besar non vulkanik, terbentuk melalui lekukan tepi laut dalam yang mengelilinginya yang merupakan salah satu persinggahan dalam lalu lintas Pelayaran Internasional. Wilayah Perairan atau laut memiliki kekayaan sumber daya kelautan yang potensial untuk dimanfaatkan dan diolah secara potensial. Wilayah perairan atau laut memiliki lingkungan usaha prospektif, yaitu sebagai wahana atau sarana tempat dilaksanakannya berbagai jenis kegiatan ekonomi dan pembangunan.

Ada banyak factor yang mempengaruhi pertumbuhan ekonomi di suatu wilayah, antara lain kebijakan pemerintah, potensi wilayah yang dipengaruhi oleh curah hujan ( Giarno dkk, 2020) dan lain-lain. Pelabuhan pula dapat menunjang aktifitas pariwisata, baik itu wisata bahari, minawisata, hingga wisata mangrove (Ahmad, Fisu \& Didiharyono, 2018). Selain itu, kondisi perekonomian secara keseluruhan di setiap daerah juga dapat dilihat dari seberapa besar jumlah belanja daerah pada daerah bersangkutan. Pengeluaran pemerintah atau belanja daerah merupakan bentuk rangsangan yang dilakukan oleh pemerintah terhadap perekonomian daerah. Semakin besar nilai belanja daerah yang dialokasikan untuk pembangunan, maka akan meningkatkan kesejahteraan penduduk. Ini berarti kondisi ekonomi di daerah tersebut juga akan meningkat.

Baik atau buruknya kondisi pelabuhan menjadi faktor penentu terbangunnya poros maritim yang kuat melalui peningkatan daya saing, efisiensi proses produksi dan distribusi serta terbangunnya integritas dan konektivitas system perekonomian (Latif dan Inne, 2017). Sayangnya, pelabuhan di Indonesia belum terkelola secara ekonomis dan efisien. Akibatnya, pelabuhan belum secara optimal berperan sebagai pendorong daya saing perekonomian nasional (Sudarmo, 2012). Hal ini sejalan dengan masih banyak ditemukan daerah yang mengalami kesulitan dalam melaksanakan pembangunan ekonominya setelah pelaksanaan otonomi daerah melalui Undang-Undang Nomor 33 Tahun 2004 mengenai pelimpahan wewenang dari pemerintah pusat kepada pemerintah daerah untuk merencanakan dan mengelola pembangunan daerahnya masing-masing berdasarkan potensi dan sumberdaya yang ada di wilayah yang bersangkutan. serta untuk mengatasi persoalan kemiskinan. 
Perhitungan PDRB telah menjadi bagian yang sangat penting dalam makro ekonomi, khususnya tentang analisis perekonomian suatu wilayah. Hasil perhitungan PDRB ini memberikan kerangka dasar yang digunakan untuk mengukur aktivitas ekonomi yang terjadi dan berlangsung dalam suatu kegiatan perekonomian. Angka- angka PDRB tersebut sebagai indikator ekonomi makro dan juga sebagai landasan evaluasi kinerja perekonomian, dan penyusunan berbagai kebijakan. Indikator ekonomi ini juga memberikan gambaran aliran seluruh nilai tambah barang dan jasa yang dihasilkan dan seluruh faktor-faktor produksi yang digunakan oleh perekonomiaan untuk menghasilkan nilai tambah barang dan jasa.

\section{Rumusan Masalah}

Bagaimana pengaruh Keberadaan Pelabuhan terhadap pertumbuhan ekonomi di Pulau Sulawesi?

\section{Tujuan}

Untuk mengetahui pengaruh keberadaan Pelabuhan terhadap pertumbuhan Ekonomi di Pulau Sulawesi, serta besaran pengaruh Keberadaan Pelabuhan terhadap pertumbuhan ekonomi di Pulau Sulawesi

\section{TINJAUAN PUSTAKA}

Pelabuhan merupakan bandar yang dilengkapi dengan bangunan-bangunan yang berfungsi sebagai pelayanan aktifitas bongkar muat barang dan naik-turun penumpang seperti dermaga, tambatan dan fasilitas-fasilitas penunjang lainnya (Fisu, 2016). Pengembangan pelabuhan berbasis logistik dilakukan karena paradigma strategi pengembangan pelabuhan saat ini tidak lagi hanya pada aspek teknis, seperti penambahan fasilitas pelabuhan baru atau memperluas area pelabuhan, namun sudah bergeser pada perspektif ekonomi. Oleh karena itu, pengembangan pelabuhan lebih ditekankan pada aspek logistic

Pelabuhan merupakan inti dalam model rantai logistic pelabuhan yang mengintegrasikan berbagai pelaku jasa logistik (termasuk penanganan, pengolahan, transportasi, pergudangan, bea cukai, distribusi, atau bahkan keuangan, perusahaan layanan bisnis, dan lain-lain) dan pelanggan (termasuk pengirim dan pengiriman perusahaan, dan lain-lain) (Fisu, Didiharyono \& Bakhtiar, 2020). Pelabuhan yang merupakan pintu gerbang utama arus barang, baik ekpor maupun impor, dan pemindah muatan antar moda transportasi. Adanya pelabuhan sebagai infrastruktur ekonomi menciptakan lapangan pekerjaan. Selain itu, pelabuhan merangsang aktivitas ekonomi yang lebih besar, misalnya tumbuhnya perusahaan dan pabrik di sekitar pelabuhan. Aktivitas ekonomi yang tinggi pada akhirnya akan menarik lebih banyak penduduk untuk tinggal didekatnya, sehingga akan membentuk daerah baru.

Teori New Economic Geography (NEG) berfokus pada pilihan antara peningkatan hasil dan biaya transportasi menyatakan bahwa ada hubungan erat antara geografi dan ekonomi. Konsentrasi aktivitas ekonomi pada suatu lokasi ditentukan oleh adanya kekuatan sentripental dan kekuatan sentrifugal. Kekuatan sentripental adalah kekuatan yang menarik ke dalam. Dalam konteks ekonomi, kekuatan sentripetal menyebabkan terjadinya konsentrasi aktivitas ekonomi. Konsentrasi mendukung besarnya pasar tenaga kerja, dan ekstemalitas positif berupa limpahan 
informasi. Sedangkan kekuatan sentrifugal adalah kekuatan yang mendorong ke luar. Kekuatan sentrifugal yang mendispersi aktivitas ekonomi dapat berupa faktor produksi yang tidak dapat berpindah seperti tanah dan sumber daya alam lainnya (Fisu, 2018). Konsentrasi aktivitas ekonomi menyebabkan harga sewa tanah mahal dan kepadatan. Pelabuhan secara natural membentuk pusat kegiatan ekonomi. Keunggulan kompetitif dari industri yang berlokasi di sekitar pelabuhan dan kemudahan hubungan transportasi antara pelabuhan dan pusat area adalah penentu utama pertumbuhan ekonomi lokal.

\section{METODE PENELITIAN}

\section{Pengumpulan Data}

Data yang digunakan merupakan data sekunder. Data sekunder adalah data yang tidak diperoleh langsung dari lapangan dan berasal dari sumber-sumber lain, seperti buku, data instansi, laporan, dan lain-lain.Pada penelitian kali ini data yang digunakan adalah data PDRB dan data pelabuhan di seluruh kabupaten/kota yang berada di Pulau Sulawesi. Data PDRB bersumber dari website Badan Pusat Statistik pada tiap kabupaten/kota di Pulau Sulawesi. Sedangkan data pelabuhan bersumber dari Keputusan Menteri Perhubungan No 414 tentang Penetapan Rencana Induk pelabuhan Nasional.

\section{Pendekatan dan Teknik Analisis}

Penelitian ini menggunakan pendekatan kuantitatif. Pendekatan kuantitatif digunakan dalam menilai korelasi antara PDRB, sebagai representasi dari indikator pengembangan wilayah. Produk Domestik Regional Bruto (PDRB) adalah jumlah nilai tambah yang dihasilkan oleh seluruh unit usaha dalam suatu daerah tertentu serta merupakan jumlah nilai barang dan jasa akhir (neto) yang dihasilkan seluruh unit ekonomi.

Untuk dapat mengetahui pengaruh variabel independen terhadap variable dependen digunakan analisis regresi Ordinary Least Square (OLS) atau regresi linier sederhana terhadap model dengan kombinasi time series dan cross section, atau disebut juga data panel (pooled data). Terdapat beberapa keunggulan dari penggunaan data panel dibandingkan dengan data time series dan cross section. Pertama, dapat memberikan sejumlah data yang lebih besar, menaikkan derajat kebebasan, mengurangi kolinearitas diantara variabel penjelas, sehingga diperoleh estimasi ekonometrik yang efisien. Kedua, memberikan informasi yang penting bagi peneliti yang tidak dapat diberikan jika menggunakan data time series dan cross section.

Keuntungan dari penggunaan data panel adalah penyatuan informasi dari data cross section dan time series yang akan mengurangi permasalahan yang timbul akibat hilangnya variabel. Kesulitan utama model penelitian dengan panel data adalah faktor pengganggu akan berpotensi mengandung gangguan yang disebabkan karena penggunaan observasi time series dan cross section, serta gangguan yang disebabkan karena gabungan keduanya. Penggunan observasi cross section memiliki potensi terjadinya ketidakkonsistenannya parameter regresi karena skala data yang berbeda, sedangkan observasi dengan data time series menyebabkan terjadinya 
autokorelasi antar observasi. Dalam penelitian sering dihadapkan oleh kendala data, jika regresi diestimasi dengan data time series atau dengan data cross section, akan terjadi estimasi yang tidak efisien terutama disebabkan karena data yang terlalu sedikit. Salah satu metode yang digunakan untuk mendapatkan data yang efisien adalah data panel.

Dalam menganalisis data panel, teknik paling sederhana mengasumsikan data gabungan yang ada menunjukkan kondisi yang sesungguhnya. Hasil analisis regresi dianggap berlaku pada semua obyek pada semua waktu. Metode ini sering disebut dengan common effect. Kelemahan asumsi tersebut adalah ketidaksesuaian model dengan keadaan yang sesungguhnya. Kondisi tiap obyek saling berbeda, bahkan satu obyek pada suatu waktu akan sangat berbeda dengan kondisi obyek tersebut pada waktu yang lain. Oleh karena itu diperlukan suatu model yang menunjukkan perbedaan konstanta antar obyek, meskipun dengan koefisien regresor yang sama. Model tersebut dikenal dengan efek tetap (fixed effect), yaitu bahwa suatu obyek memiliki konstanta yang tetap besarnya untuk berbagai periode waktu.

Persamaan regresi linier sederhana yaitu sebagai berikut:

$Y=a+b X$

Dimana:

$$
\begin{aligned}
a & =\frac{\sum \quad Y \sum \quad x^{2}-\sum \quad Y \sum \quad X Y}{n \sum X^{2}-\left(\begin{array}{ll}
\Sigma & X^{2}
\end{array}\right)} \\
b & =\frac{n \sum \quad X Y-\sum \quad X \sum \quad Y}{n \sum X^{2}-\left(\begin{array}{ll}
\Sigma & x^{2}
\end{array}\right)}
\end{aligned}
$$

\section{Keteragan:}

$$
\begin{array}{ll}
Y & =\text { Variabel Terikat } \\
X & =\text { Variabel Bebas } \\
a & =\text { Konstanta (nilai Y apabila } X=0) \\
b & =\text { Koefiseien Regresi (nilai peningkatan maupun penurunan) }
\end{array}
$$

\section{ANALISIS DAN PEMBAHASAN}

Salah satu indikator yang penting untuk mengetahui kondisi ekonomi di suatu daerah atau provinsi dalam suatu periode tertentu ditunjukkan oleh data Produk Domestik Regional Bruto (PDRB). Nilai PDRB ini akan menjelaskan sejauh mana kemampuan daerah dalam mengelola atau memanfaatkan sumberdaya yang ada. Setelah dilakukan pengujian data secara statistik, maka pada penelitian ini dikeluarkan data-data yang berpotensi menggangu analisis yang akan dilakukan. Data yang dimaksud adalah data jumlah pelabuhan pada kabupaten/kota tertentu yang memiliki karakteristik wilayah kepulauan dan memiliki sangat banyak pelabuhan yang orientasi utamanya adalah pelayanan penyeberangan antar pulau. Seperti Kabupaten Kepulauan Sangihe yang memiliki 20 pelabuhan, Kabupaten Kepulauan Talaud 14 pelabuhan, Kabupaten banggai Kepulauan 65 pelabuhan, dan lain-lain. Tabel 1 menunjukkan PDRB Kabupaten / Kota di Pulau Sulawesi atas dasar harga berlaku 2013-2016 dan jumlah pelabuhan. 
Tabel 1. PDRB Kabupaten/Kota di Pulau Sulawesi Atas Dasar Harga Belaku tahun 2018 selama periode tahun 2013-2016.

\begin{tabular}{|c|c|c|c|c|c|c|c|c|c|c|}
\hline \multirow{2}{*}{ No } & \multirow{2}{*}{ Kabupaten/Kota } & \multicolumn{4}{|c|}{$\begin{array}{l}\text { Pruduk Domestik Region al Bru to (PDRB) Atas H arga Berlaku (Juta } \\
\text { Rupiah) }\end{array}$} & \multirow{2}{*}{$\begin{array}{l}\text { Rat a-rata } \\
\text { Pertu mbuh an } \\
\text { Ekon omi ( }(\%)\end{array}$} & \multicolumn{4}{|c|}{ Pelabuhan } \\
\hline & & 2013 & 2014 & 2015 & 2016 & & PL & $p p$ & PR & pu \\
\hline 1 & Kab. Bantaeng & $4.963 .797,11$ & $5.579 .335,48$ & $6.283 .514,26$ & $6.951 .076,49$ & 11,88193 & 1 & 0 & 0 & 0 \\
\hline 2 & Kab. Bams & $4.433 .528,97$ & $4.942 .362,22$ & $5.462 .419,08$ & $5.970 .101,11$ & 10,43115 & 2 & 2 & 0 & 0 \\
\hline 3 & Kab. Bone & $19.866 .945,25$ & $23.296 .117,71$ & $26.301 .035,26$ & $29.405 .396,27$ & 13,98756 & 5 & 1 & 2 & 0 \\
\hline 4 & Kab. Bulukumba & $8.374 .049,09$ & $9.568 .396,97$ & $10.820 .012,27$ & $12.174 .855,20$ & 13,28828 & 2 & 1 & 0 & 0 \\
\hline 5 & Kab. Enrekang & $4.631 .503,26$ & $5.240 .376,39$ & $5.901 .552,14$ & $6.412 .457,10$ & 11,47347 & 0 & 0 & 0 & 0 \\
\hline 6 & Kab. Gowa & $12.044 .433,41$ & $13.752 .085,30$ & $15.524 .364,50$ & 17.271 .382 .57 & 12,77289 & 0 & 0 & 0 & 0 \\
\hline 7 & Kab. Jeneponto & $6.155 .880,02$ & $7.001 .194,66$ & $7.872 .787,82$ & $8.645 .022,92$ & 11,99665 & 0 & 0 & 1 & 0 \\
\hline 8 & Kab. Lumb & $9.018 .397,18$ & $10.362 .514,60$ & $11.860 .659,19$ & $13.041 .819,79$ & 13,10672 & 2 & 0 & 0 & 0 \\
\hline 9 & Kab. Luwu Utara & $7.590 .616,62$ & $8.697 .311,80$ & $9.790 .450,30$ & $10.800 .790,90$ & 12,48938 & 2 & 0 & 0 & 0 \\
\hline 10 & Kab. Maros & $13.462 .074,92$ & $15.585 .841,29$ & $17.869 .496,17$ & $19.451 .379,32$ & 13,09348 & 0 & 0 & 0 & 0 \\
\hline 11 & Kab. Pinrang & $11.366 .878,82$ & $13.142 .421,55$ & $14.736 .957,03$ & $16.411 .362,33$ & 13,03833 & 2 & 0 & 1 & 0 \\
\hline 12 & $\begin{array}{l}\text { Kab. Sidenreng } \\
\text { Rappang }\end{array}$ & $8.047 .481,60$ & $9.309 .292,77$ & $10.770 .430,52$ & 11.955 .377 .83 & 14,12564 & 0 & 0 & 0 & 0 \\
\hline 13 & Kab. Sinjai & $6.484 .191,29$ & $7.517 .873,68$ & $8.305 .892,43$ & $9.189 .912,49$ & 12,35560 & 2 & 1 & 0 & 0 \\
\hline 14 & Kab. Soppeng & $6.172 .928,59$ & $6.843 .608,24$ & $7.920 .144,95$ & $8.947 .107,05$ & 13,18728 & 0 & 0 & 0 & 0 \\
\hline 15 & Kab. Takalar & $5.881 .371,02$ & $6.820 .886,52$ & $7.755 .771,27$ & $8.576 .540,04$ & 13,42111 & 1 & 0 & 1 & 0 \\
\hline 16 & Kab. Tanah Toraja & $4.276 .116,23$ & $4.907 .411,30$ & $5.484 .920,07$ & $6.084 .149,83$ & 12,48547 & 0 & 0 & 0 & 0 \\
\hline 17 & Kab. Toraja Utara & $5.031 .503,42$ & $5.880 .063,42$ & $6.822 \cdot 150,23$ & $7.788 .794,40$ & 15,68528 & 0 & 0 & 0 & 0 \\
\hline 18 & Kab. Wajo & $13.655 .378,05$ & $15.118 .520,53$ & $16.540 .503,20$ & $17.897 .717,74$ & 9,44191 & 2 & 0 & 2 & 0 \\
\hline 19 & KOTAMLAKASS AR & $100.392 .977,47$ & $114.309 .180,44$ & $127.623 .171,72$ & $143.148 .662,00$ & 12,55806 & 0 & 1 & 0 & 1 \\
\hline 20 & KOTAPALOPO & $4.748 .586,46$ & $5.351 .284,90$ & $5.906 .480,42$ & $6.550 .688,67$ & 11,32465 & 0 & 1 & 0 & 0 \\
\hline 21 & KOTAPAREPARE & $4.434 .865,41$ & $5.062 .244,63$ & $5.543 .147,32$ & $6.111 .149,27$ & 11,29775 & 0 & 2 & 0 & 0 \\
\hline 22 & Kab. Bang gai & $11.230 .557,26$ & $15.224 .150,54$ & $20.900 .901,99$ & $23.661 .262,00$ & 28,68492 & 0 & 3 & 1 & 0 \\
\hline 23 & Kab. Bang gai Laut & $1.517 .375,71$ & $1.686 .882,20$ & $1.850 .487,04$ & $2.020 .670,96$ & 10,02213 & 0 & 0 & 0 & 0 \\
\hline 24 & Kab. Morovali & $7.552 .652,60$ & $12.818 .240,60$ & $14.665 .635,50$ & $17.548 .612,00$ & 34,59622 & 2 & 3 & 1 & 0 \\
\hline 25 & Kab. Moro vali Utara & $6.618 .001,50$ & $7.837 .097,70$ & $8.356 .351,30$ & $9.165 .058,00$ & 11,57475 & 0 & 0 & 0 & 0 \\
\hline 26 & Kab. Parigi Moutong & $11.767 .485,26$ & $13.261 .195,55$ & $14.318 .048,26$ & $15.921 .846,91$ & 10,62143 & 1 & 0 & 1 & 0 \\
\hline 27 & Kab. Poso & $6.022 .259,67$ & $6.688 .914,41$ & $7,354.996,51$ & $8.087 .110,97$ & 10,32727 & 0 & 1 & 0 & 0 \\
\hline 28 & Kab. Sigi & $6.119 .245,00$ & $6.735 .071,00$ & $7.371 .944,00$ & $7.931 .264,00$ & 9,03566 & 0 & 0 & 0 & 0 \\
\hline 29 & Kab. Tolitoli & $5.489 .820,60$ & $6.081 .113,90$ & $6.600 .489,40$ & $7.230 .287,00$ & 9,61773 & 1 & 1 & 0 & 0 \\
\hline 30 & Kab. Palu & $15.135 .980,91$ & $17.179 .020,44$ & $18.659 .652,23$ & $20.593 .579,00$ & 10,82698 & 0 & 0 & 0 & 1 \\
\hline 31 & Kab. Boaleno & $3.263 .420,72$ & $3.704 .910,85$ & $4.166 .574,49$ & $4.595 .717,18$ & 12,09632 & 1 & 0 & 1 & 0 \\
\hline 32 & Kab. Bone Bolango & $2.768 .335,08$ & $3.137 .838,68$ & $3.509 .327,97$ & $3.867 .899,50$ & 11,80140 & 0 & 0 & 0 & 0 \\
\hline 33 & Kab. Gorontalo & $7.939 .141,16$ & $8.983 .746,52$ & $9.994 .574,75$ & $10.889 .868,20$ & 11,12240 & 0 & 1 & 0 & 0 \\
\hline
\end{tabular}




\begin{tabular}{|c|c|c|c|c|c|c|c|c|c|c|}
\hline \multirow{2}{*}{ No } & \multirow{2}{*}{ Kabupaten/Kota } & \multicolumn{4}{|c|}{$\begin{array}{l}\text { Pruduk Domestik Region al Bruto (PDRB) Atas H arga Berlaku (Juta } \\
\text { Rupiah) }\end{array}$} & \multirow{2}{*}{$\begin{array}{l}\text { Rat a-rata } \\
\text { Pertu mbuh an } \\
\text { Ekon omi ( } 96)\end{array}$} & \multicolumn{4}{|c|}{ Pelabuhan } \\
\hline & & 2013 & 2014 & 2015 & 2016 & & PL & $\mathrm{pp}$ & $P R$ & PU \\
\hline 34 & Kab. Gorontalo Utara & $1.990 .132,50$ & $2.264 .409,95$ & $2.561 .068,40$ & $2.812 .483,70$ & 12,23320 & 2 & 2 & 0 & 0 \\
\hline 35 & Kab. Pohu wato & $4.063 .823,00$ & $4.569 .631,79$ & $5.118 .640,31$ & $5.578 .018,84$ & 11,14518 & 3 & 0 & 1 & 0 \\
\hline 36 & KOTA GORONT ALO & $5.192 .432,48$ & $5.791 .194,59$ & $6.467 .006,95$ & $7.102 .204,98$ & 11,00774 & 0 & 0 & 0 & 0 \\
\hline 37 & $\begin{array}{l}\text { Kab. Bolaang } \\
\text { Mongond ow }\end{array}$ & $4.744 .751,79$ & $5.351 .194,94$ & $5.948 .198,99$ & $6.526 .270,00$ & 11,21874 & 0 & 1 & 0 & 0 \\
\hline 38 & \begin{tabular}{|l|} 
Kab. Bolaang \\
Mongond ow Selatan \\
\end{tabular} & $1.255 .644,00$ & $1.410 .469,00$ & $1.576 .872,00$ & $1.727 .721,00$ & 11,23146 & 1 & 0 & 1 & 0 \\
\hline 39 & $\begin{array}{l}\text { Kab. Bolaang } \\
\text { Mongond ow Timus }\end{array}$ & 1.672 .357 .48 & $1.919 .098,71$ & $2.208 .001,56$ & $2.422 .627,40$ & 13,17618 & 2 & 0 & 0 & 0 \\
\hline 40 & \begin{tabular}{|l|} 
Kab. Bola ang \\
Mongond owUtara
\end{tabular} & $1.543 .373,00$ & $1.720 .623,00$ & $1.923 .711,00$ & $2.103 .411,50$ & 10,87637 & 1 & 0 & 0 & 0 \\
\hline 41 & \begin{tabular}{|l|} 
Kab. Kepulauan Siau \\
Tangulandang Biaro \\
\end{tabular} & $1.380 .749,79$ & $1.572 .345,49$ & $1.765 .100,83$ & $1.950 .876,00$ & 12,22007 & 0 & 0 & 0 & 0 \\
\hline 42 & Kab. Minahasa & $10.788 .255,00$ & $12.045 .303,15$ & $13.326 .819,15$ & $14.496 .499,68$ & 10,35601 & 2 & 0 & 0 & 0 \\
\hline 43 & $\begin{array}{l}\text { Kab. Minahasa } \\
\text { Selatan }\end{array}$ & $5.302 .543,36$ & $6.076 .177,57$ & $6.665 .741,99$ & $7.244 .498,30$ & 10,99177 & 1 & 0 & 0 & 0 \\
\hline 44 & \begin{tabular}{|l|} 
Kab. Minahasa \\
Tenggara \\
\end{tabular} & $3.206 .191,93$ & $3.609 .706,92$ & $3.962 .476,21$ & $4.365 .600,40$ & 10,84394 & 1 & 0 & 1 & 0 \\
\hline 45 & KOTABITUNG & $10.517 .424,71$ & $11.634 .276,99$ & $12.682 .455,27$ & $14.084 .447,14$ & 10,22768 & 0 & 0 & 1 & 1 \\
\hline 46 & \begin{tabular}{|l|l|} 
KOTA \\
KOTAMUBAGU \\
\end{tabular} & $2.177 .143,39$ & $2.455 .915,67$ & 2706911,37 & $2933.218,00$ & 10,46162 & 0 & 0 & 0 & 0 \\
\hline 47 & KOTAMANADO & $22.497 .621,50$ & $25.557 .060,08$ & $28.354 .669,33$ & $31.133 .345,90$ & 11,44839 & 1 & 1 & 0 & 0 \\
\hline 48 & KOTA TOMOHON & $2.696 .533,71$ & 2.990 .642 .25 & $3.222 .005,28$ & 3.593 .526 .50 & 10,05796 & 0 & 0 & 0 & 0 \\
\hline 49 & Kab. Nam asa & $1.932 .278,03$ & $2.127 .973,44$ & $2.334 .329,35$ & $2.530 .560,00$ & 9,41043 & 0 & 0 & 0 & 0 \\
\hline 50 & Kab. Mamuju & $7.326937,29$ & $8.223 .881,17$ & $9.091 .964,57$ & $10.061 .750,00$ & 11,15459 & 7 & 0 & 1 & 1 \\
\hline 51 & Kab. Mam uju Tengah & $2.050 .680,00$ & $2.302 .620,00$ & $2.487 .540,00$ & $2.697 .560,00$ & 9,58647 & 0 & 0 & 0 & 0 \\
\hline 52 & \begin{tabular}{|l} 
Kab. Nam uju \\
Utara Pas ang Kayu
\end{tabular} & $6.735 .554,23$ & $7.571 .170,53$ & $8.046 .178,33$ & $8.828 .270,00$ & 9,46666 & 1 & 0 & 1 & 0 \\
\hline 53 & $\begin{array}{l}\text { Kab. Polevali } \\
\text { Mandar }\end{array}$ & $8.234 .999,00$ & $9.412 .309,00$ & $10.369 .883,00$ & $11.382 .730,00$ & 11,41242 & 2 & 0 & 1 & 0 \\
\hline 54 & Kab. Bon bana & $3.985 .950,01$ & $4.529 .899,39$ & $4.980 .791,71$ & $5.476 .945,60$ & 11,18724 & 5 & 0 & 0 & 0 \\
\hline 55 & Kab. Buton Selatan & $1.822 .717,03$ & $1.995 .437,90$ & $2.235 .861,20$ & $2.463 .178,40$ & 10,56384 & 0 & 0 & 0 & 0 \\
\hline 56 & Kab. Buton Tengah & $1.483 .529,28$ & $1.593 .269,70$ & $1.799 .872,00$ & $1.975 .777,50$ & 10,04589 & 0 & 0 & 0 & 0 \\
\hline 57 & Kab. Buton Utara & $1.979 .850,01$ & $2.165 .457,32$ & $2.406 .398,06$ & $2.645 .490,48$ & 10,14569 & 2 & 0 & 1 & 0 \\
\hline 58 & Kab. Kolaka & $15.291 .372,03$ & $17.171 .715,83$ & $18.367 .826,92$ & $21.341 .933,57$ & 11,81810 & 5 & 1 & 2 & 0 \\
\hline 59 & Kab. Kolaka Utara & $5.281 .040,00$ & 5.892 .182 .51 & $6.608 .051,50$ & $7.262 .120,30$ & 11,20664 & 1 & 1 & 1 & 0 \\
\hline 60 & Kab. Kona we & $5.509 .917,19$ & $6.103 .266,10$ & $6.655 .749,05$ & $7.231 .385,90$ & 9,48990 & 2 & 0 & 0 & 0 \\
\hline 61 & Kab. Kona ve Selatan & $7.311 .022,99$ & $8.340 .404,90$ & $9.220 .785,82$ & $10.200 .298,30$ & 11.75278 & 1 & 0 & 1 & 0 \\
\hline 62 & Kab. Kona we Utara & $2.435 .077,89$ & $2.703 .274,79$ & $2.959 .599,31$ & $3.264 .232,69$ & 10,26299 & 3 & 0 & 0 & 0 \\
\hline 63 & Kab. Muna & $4.440 .049,38$ & $4.966 .139,70$ & $5.455 .769,26$ & $5.921 .618,20$ & 10,08225 & 2 & 1 & 0 & 0 \\
\hline 64 & Kab. Muna Barat & $1.551 .504,02$ & $1.756 .361,02$ & $1.965 .173,71$ & $2.141 .329,79$ & 11,35220 & 0 & 0 & 0 & 0 \\
\hline 65 & Kab. Wakatobi & $2.575 .657,50$ & $2.914 .888,00$ & $3.304 .672,80$ & $3.629 .611,80$ & 12,12519 & 2 & 1 & 1 & 0 \\
\hline 66 & KOTABAU-BAU & $5.324 .200,00$ & $5.999 .020,00$ & $6.743 .848,00$ & 7.508 .275 .50 & 12,14186 & 0 & 1 & 0 & 0 \\
\hline 67 & KOTAKENDARI & $13.411 .291,19$ & $15.188 .257,20$ & $17.235 .583,56$ & $18.668 .327,00$ & 11,68072 & 0 & 2 & 0 & 0 \\
\hline
\end{tabular}


Berdasarkan Tabel 1 diatas, PDRB per kapita tertinggi selama 2013-2016 dimiliki oleh Kota Makassar dengan PDRB per kapita pada tahun 2013 sebesar Rp 100,392,977.47 dan pada tahun 2016 dengan PDRB per kapita sebesar Rp 143,148,662.00. Kemudian Kota Manado pada tahun 2016 dengan PDRB sebesar Rp 31,133,345.90. Kabupaten Bone pada tahun 2012 dengan PDRB sebesar Rp 29,405,396.27. Sedangkan PDRB per kapita terendah pada tahun 2012 dimiliki oleh Kabupaten Bolaang Mongondow Selatan sebesar Rp 1,727,721.00.

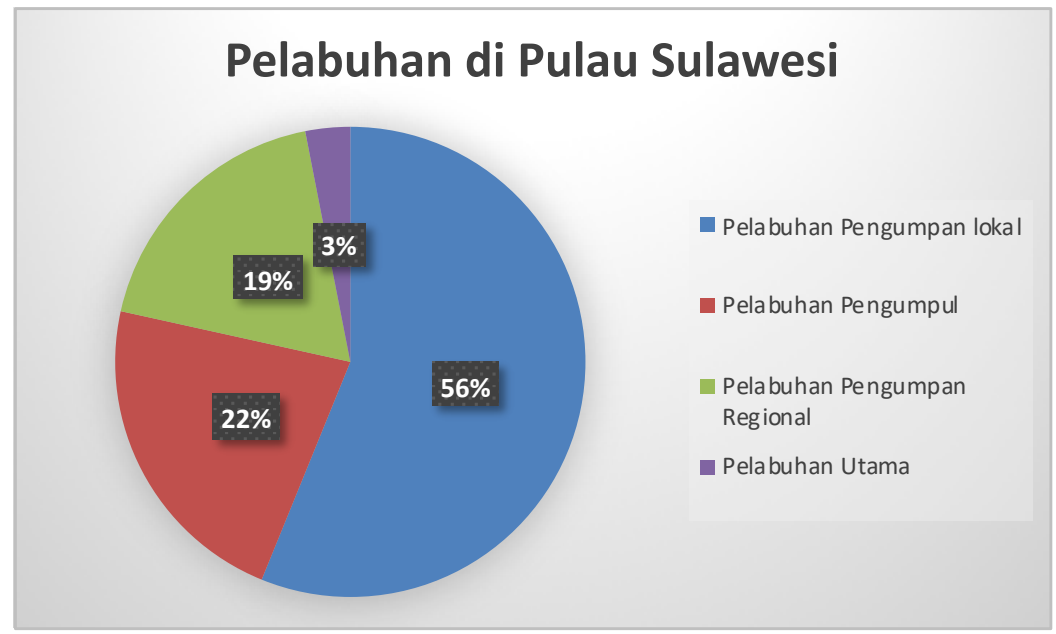

Gambar 1. Persentase Jumlah pelabuhan di Sulawesi berdasarkan Jenisnya

Dari diagram di atas dapat dilihat bahwa pelabuhan-pelabuhan yang berada di Sulawesi didominasi oleh pelabuhan pengumpan lokal yaitu sebesar 56\%. Hal ini dikarenakan banyaknya kabupaten/ kota di Pulau Sulawesi yang memiliki karakteristik kepulauan, sehingga hampir tiap pulau yang berpenghuni memiliki pelabuhan. Selain itu terdapat 4 pelabuhan utama di Pulau Sulawesi, antara lain yaitu Pelabuhan Soekarno Hatta di Makassar Sulawesi Selatan, dan pelabuhan Bitung di Manado Sulawesi Utara.

Data yang ada kemudian dikonversi dengan metode skoring atau pembobotan mengingat semua jenis pelabuhan yang ada tidak dapat disamakan fungsi dan peranannya. Menurut Fisu (2018) metode pembobotan atau skoring yang merupakan representasi dari tingkat pemenuhan kriteria dari suatu alternatif yang merupakan hasil perkalian dari skor alternative terhadap variabel kriteria dengan besarnya bobot setiap kriteria. Dapat dikatakan bahwa terdapat dua kondisi yang dijadikan sebagai patokan dalam menentukan pengaruh keberadaan pelabuhan terhadap pertumbuhan ekonomi. Kondisi pertama yaitu dengan mengunakan seluruh jenis pelabuhan sebagai pengaruh terhadap pertumbuhan ekonomi dan diberikan bobot pada masing-masing jenis pelabuhan tersebut. Berikut adalah bobot yang diberikan pada masing-masing jenis pelabuhan di Pulau Sulawesi: 
Tabel 2. Pembobotan Jenis Pelabuhan Kabupaten/Kota di Pulau Sulawesi

\begin{tabular}{c|c}
\hline Jenis Pelabuhan & Bobot/ Skoring \\
\hline Pelabuhan Pengumpan Lokal (PL) & 1 \\
\hline Pelabuhan Pengumpul (PP) & 2 \\
\hline Pelabuhan Pengumpan Regional (PR) & 3 \\
\hline Pelabuhan Utama (PU) & 4 \\
\hline
\end{tabular}

Sementara itu untuk kondisi kedua untuk menilai tingkat pengaruh keberadaan pelabuhan terhadap pertumbuhan ekonomi, yaitu dengan menggunakan hanya tiga pelabuhan yang berarti tidak menggunakan salah satunya. Hal ini dilakukan guna untuk mengetahui kriteria pelabuhan yang memiliki pengaruh kuat terhadap pertumbuhan ekonomi.

Setelah dilakukan beberapa pengujian data bahwasanya terdapat beberapa kabupaten yang berpotensi menggangu data secara statistik, sehingga beberapa Kabupaten yang bersifat Kepulauan tidak dipergunakan dalam analisis data karena memiliki banyak pelabuhan, di mana pelabuhan-pelabuhan tersebut merupakan pelabuhan pengumpul yang fungsi utamanya bukan sebagai fungsi perekonomian, namun lebih kepada fungsi pelayanan. Kabupaten tersebut diantaranya Kabupaten Banggai dan Kepulauan, Kabupaten Kepulauan Talaud, Kabupaten Konawe Kepulauan, dan lain-lain.

Tabel 3. Analisis Data Pengaruh Keberadaaan Pelabuhan Terhadap Pertumbuhan Ekonomi

\begin{tabular}{|c|c|c|c|c|c|}
\hline $\begin{array}{c}\text { Jenis Pelabuhan } \\
(\mathbf{Y})\end{array}$ & Bobot & Variabel (X) & $\mathbf{R}^{\mathbf{2}}$ & P-Value & Model \\
\hline PL & 1 & $\mathrm{X}=$ & & & $\mathrm{Y}=10.37522+$ \\
PP & 2 & $\begin{array}{c}1+(\mathrm{PL} * 1)+(\mathrm{PP} * 2)+ \\
(\mathrm{PR} * 3)+(\mathrm{PU} * 4)\end{array}$ & 0.12251 & 0.00369 & $0.38815 \mathrm{X}$ \\
PR & 3 & & & \\
\hline
\end{tabular}

Hasil regresi pada Tabel 3 dan 4 Ditunjukkan dalam output regresi Excel di bawah ini:

Tabel 3: Summary output

\begin{tabular}{|l|l|}
\hline \multicolumn{2}{|l|}{ Regression Statistics } \\
\hline Multiple R & 0.35001 \\
R Square & 0.12251 \\
Adjusted R Square & 0.10901 \\
Standard Error & 3.52670 \\
Observations & 67 \\
\hline
\end{tabular}


Tabel 4. Annova

\begin{tabular}{|l|c|c|c|c|c|}
\hline & $d f$ & $S S$ & $M S$ & $F$ & Significance F \\
\hline Regression & 1 & 112.87105 & 112.87105 & 9.07494 & 0.00368 \\
Residual & 65 & 808.44761 & 12.43765 & & \\
Total & 66 & 921.31866 & & & \\
\hline
\end{tabular}

\begin{tabular}{|l|c|c|c|c|c|c|c|c|}
\hline & Coefficients & $\begin{array}{c}\text { Standard } \\
\text { Error }\end{array}$ & t Stat & P-value & $\begin{array}{c}\text { Lower } \\
95 \%\end{array}$ & $\begin{array}{c}\text { Upper } \\
95 \%\end{array}$ & $\begin{array}{c}\text { Lower } \\
95.0 \%\end{array}$ & $\begin{array}{c}\text { Upper } \\
95.0 \%\end{array}$ \\
\hline Intercept & 10.37522 & 0.69867 & 14.84 & 0,00000 & 8.9798 & 11.770 & 8.9798 & 11.7705 \\
$\mathrm{X}_{1}$ & 0.38815 & 0.12884 & 3.012 & 0.00368 & 0.1308 & 0.6454 & 0.1308 & 0.6454 \\
\hline
\end{tabular}

Model regresi yang ditunjukkan pada tabel diatas diperoleh $\mathrm{R}^{2}$ sebesar $=0.12251$ artinya bahwa sebesar $12.251 \%$ variabel keberadaan pelabuhan dan sisanya $87.749 \%$ dijelaskan oleh variabel lain diluar model.

Setelah dilakukan beberapa analisis terhadap data yang ada, diperoleh bahwa Pelabuhan Pengumpan Lokal berpengaruh terhadap hasil regresi, di mana diketahui bahwa Pelabuhan Pengumpan Lokal yang fungsi utamanya bukan sebagai fungsi perekonomian, namun lebih kepada fungsi pelayanan. Dimana pelabuhan tersebut berpengaruh terhadap data secara statistik sehingga di coba untuk menghilangkan pelabuhan tersebut. Tabel 4 dibawah menunjukkan hubungan maupun hasil

Tabel 4. Analisis Data Pengaruh Keberadaaan Pelabuhan Terhadap Pertumbuhan Ekonomi

\begin{tabular}{|c|c|c|c|c|c|}
\hline $\begin{array}{c}\text { Jenis } \\
\text { Pelabuhan (Y) }\end{array}$ & Bobot & Rumus & $\mathbf{R}^{2}$ & P-Value & Model \\
\hline PP & 2 & $\mathrm{X}=$ & & & $\mathrm{Y}=9.90537+$ \\
PR & 3 & $\begin{array}{c}1+(\mathrm{PP} * 2)+(\mathrm{PR} * 3) \\
+\left(\mathrm{PU}^{*} 4\right)\end{array}$ & 0.20394 & 0.00012 & $0.66897 \mathrm{X}$ \\
\hline PU & 4 & & & \\
\hline
\end{tabular}

Model regresi yang ditunjukkan pada tabel diatas diperoleh $\mathrm{R}^{2}$ sebesar $=0.203941$ artinya bahwa sebesar $20.394 \%$ variabel keberadaan pelabuhan dan sisanya $79.606 \%$ dijelaskan oleh variabel 
lain diluar model. Dan nilai P-Value yang dihasilkan sebesar 0.00012 dengan model regresi $\mathrm{Y}=$ $9.90537+0.66897 \mathrm{X}$.

\section{KESIMPULAN DAN REKOMENDASI}

Kesimpulan

Hasil analisis menunjukkan keberadaan pelabuhan pengumpan regional, pelabuhan pengumpan lokal dan pelabuhan utama berpengaruh terhadap PDRB dan pertumbuhan ekonomi dengan model regresi sederhana yang dilakukan diperoleh P-Value sebesar 0.000125 R Square sebesar $=0,20394$ artinya bahwa pengaruh keberadaan pelabuhan terhadap PDRB hanya memiliki kontribusi sebesar 20,4\%. Pengaruh tersebut signifikan karena hasil pengujian ditemukan nilai $\mathrm{F}$ hitung sebesar 16,65237. Dengan demikian dapat disimpulkan bahwa pelabuhan pengumpan regional, pelabuhan pengumpan lokal dan pelabuhan utama memiliki pengaruh yang kecil terhadap PDRB dan pertumbuhan ekonomi di pulau Sulawesi.

Sedangkan pada daerah yang tidak memiliki pelabuhan pengumpan lokal, PDRB dan pertumbuhan ekonomi rendah dengan hasil penelitian sebesar $1.1098 \%$. Dengan model regresi sederhana yang dilakukan diperoleh $\mathrm{R}$ Square sebesar $=0,01098 \%$ artinya bahwa sebesar $1.1098 \%$ pelabuhan tersebut tidak berpengaruh besar terhadap PDRB dan pertumbuhan ekonomi.

Hal ini tentu saja sesuai dengan penelitian yang dilakukan bahwa Semakin banyak pelabuhan pengumpan regional, pelabuhan pengumpan lokal dan pelabuhan utama, maka semakin meningkat nilai PDRB dan pertumbuhan ekonomi di daerah tersebut karena proses transportasi barang dan jasa yang baik dan lancar akan mengakibatkan tingkat kesejahteraan penduduknya merata. Berbeda dengan keberadaan pelabuhan pengumpan lokal yang tidak signifikan terhadap PDRB dan pertumbuhan ekonomi pulau Sulawesi. Oleh karena itu, dengan adanya peningkatan pelabuhan pengumpan lokal akan dapat menurunkan PDRB dan pertumbuhan ekonomi di daerah tersebut. Selain itu, penerimaan daerah dari pelabuhan pengumpan lokal tidak begitu optimal karena penerimaan pajak dan retribusi daerah tidak maksimal dikumpulkan oleh pemerintah daerah karena pelabuhan pengumpan lokal hanya berfungsi sebagai penyeberangan masyarakat daerah setempat. Pelabuhan pengumpan regional, pelabuhan pengumpan lokal dan pelabuhan utama merupakan salah satu faktor yang mempengaruhi PDRB pulau Sulawesi dengan bertambahnya ketiga pelabuhan tersebut berarti terjadi pertumbuhan ekonomi karena pertumbuhan ekonomi diukur dari Produk Domestik Regional Bruto (PDRB), maka peningkatan PDRB berarti peningkatan pendapatan.

\section{Rekomendasi}

Pertumbuhan PDRB Pulau Sulawesi yang meningkat hendaknya lebih didukung dengan adanya penambahan pelabuhan pengumpan regional, pelabuhan pengumpan lokal dan pelabuhan utama. Pemerintah daerah pulau Sulawesi harus konsisten dalam merealisasikan penambahan 
pelabuhan tersebut yang berorientasi pada peningkatan pendapatan daerah sehingga tingkat kesejahteraan masyarakat dapat meningkat, sehingga pertumbuhan ekonomi dan PDRB juga meningkat.

\section{REFERENCES}

Ahmad, A., Fisu, A. A., \& Didiharyono, D. (2018). Analisis Potensi Ekosistem Mangrove Sebagai Pengembangan Objek Wisata (Studi Kasus: Kabupaten Wakatobi). Prosiding, 4(1). Prosiding Seminar Nasional UNCP Buku 2. Vol 2 No 1.

Elfrida Gultom. Pelabuhan Indonesia Sebagai Penyumbang Devisa Negara Dalam Perspektif Hukum Bisnis. Kanun Jurnal Ilmu Hukum. Vol.10, No.03, hal 419-444 (2017)

Fisu AA. (2018). "Analisis Kebutuhan Fasilitas Sisi Laut Pelabuhan Terminal Khusus PLTGU Lombok". Jurnal Pena Teknik Vol.02 No.02, September 2018. 53 - 65

Fisu, A. A. (2018). ANALISIS LOKASI PADA PERENCANAAN TERMINAL TOPOYO MAMUJU TENGAH. PENA TEKNIK: Jurnal IImiah IImu-IImu Teknik, 3(1), 1-12.

Fisu, A. A. (2016). Potensi Demand Terhadap Pengembangan Kanal Jongaya \& Panampu Sebagai Moda Transportasi (Waterway) Di Kota Makassar. Jurnal Manajemen Transportasi \& Logistik, 3(3), 285-298.

Fisu, A. A. (2019). TINJAUAN KECELAKAAN LALU LINTAS ANTAR WILAYAH PADA JALAN TRANS PROVINSI SULAWESI SELATAN. PENA TEKNIK: Jurnal IImiah IImu-IImu Teknik, 4(1), 53-65.

Fisu, A. A. (2016). Analisis dan Konsep Perencanaan Kawasan Pelabuhan Kota Penajam Sebagai Pintu Gerbang Kab. Penajam Paser Utara kalimantan Timur. PENA TEKNIK: Jurnal IImiah IImu-IImu Teknik, 1(2), 125-136

Fisu, A. A., \& Marzaman, L. U. (2018). Pemetaan Partisipatif Kampung Pesisir Kelurahan Tallo Kota Makassar. To Maegal Jurnal Pengabdian Masyarakat, 1(1), 22-28.

Fisu, A. A., \& Didiharyono, D. (2019). Penandaan Batas Area Perhutanan Sosial Dengan Pendekatan Partisipatif Pada Desa Ilanbatu Uru Kabupaten Luwu. To Maega| Jurnal Pengabdian Masyarakat, 2(2), 1-10. 
Fisu, A. A, Didiharyono \& Bakhtiar (2020). Economic \& Financial Analysis of Tarakan Fishery Industrial Estate Masterplan. International Conference on Environment and Technology. IOP Conference Series Vol 469

Fisu, A. A. (2019). IDENTIFIKASI AWAL LOKASI RENCANA PELABUHAN DI TELUK PRIGI KABUPATEN TRENGGALEK. https://osf.io/preprints/inarxiv/c82h6/

Fisu A. A. (2019). "Studi Awal Lokasi Rencana Pelabuhan Di Teluk Prigi Kabupaten Trenggalek". https://osf.io/preprints/inarxiv/p5ec4/

Fisu, A. A. (2019). Analisis Kelayakan Ekonomi \& Finansial pada Masterplan Kawasan Industri Perikanan Kota Tarakan. https://doi.org/10.31227/osf.io/96yzu.

Fisu, A. A., Tufail, D. N., Procyoniana, S. B., \& Nugraha, R. M. (2019). TINJAUAN TRANSPORTASI PADA KAWASAN KOMERSIL (STUDI KASUS JALAN CIHAMPELAS KOTA BANDUNG). https://doi.org/10.31227/osf.io/s9u2a

Fisu, A. A. (2020). Analisis Perencanaan Pengembangan Fasilitas Terminal Khusus PLTU Nagan Raya Aceh. https://doi.org/10.31227/osf.io/zcxng

Giarno, D. D., Fisu, A. A., \& Mattingaragau, A. (2020). Influence Rainy and Dry Season to Daily Rainfall Interpolation in Complex Terrain of Sulawesi. International Conference on Environment and Technology. IOP Conference Series Vol 469

Keputusan Menteri Perhubungan republic Indonesia No 414 Tahun 2013 Tentang Penetapan Rencana Induk Pelabuhan Republik Indonesia

Mandasari, Tridoyo Kusumastanto, Heti Mulyati. (2017). Analisis Kebijakan Ekonomi Pengembangan pelabuhan di Provinsi Aceh. Jurnal Ekonomi dan Pembangunan Indonesia, Vol.18, No.01.hal 92-108

Marsus, B., Indriani, N. K., Darmawan, V., \& Fisu, A. A. (2020). PENGARUH PANJANG INFRASTRUKTUR JALAN TERHADAP PDRB DAN PERTUMBUHAN EKONOMI KOTA PALOPO. https://osf.io/preprints/inarxiv/xf7dh/

Marzaman, L. U., Hafid, Z. A., Fisu, A. A., \& Nurhijrah, N. (2019). PLACE MAKING WORKSHOP BATUPASI SUB DISTRICT PALOPO CITY.To Maegal Jurnal Pengabdian Masyarakat, 2(1), 1-8. 
Nurhijrah, N., \& Fisu, A. A. (2020). Place Memory Masyarakat pada Bangunan Cagar Budaya di Kota Palopo. RUAS (Review of Urbanism and Architectural Studies), 17(2), 63-70.

Peraturan Meteri Perhubungan No. 51 Tahun 2015 Tentang Penyelenggaraan Pelabuhan laut

Rahman, Yozi Aulia, Ayunda Lintang Chamelia. (2015). Faktor-faktor yang Mempengaruhi PDRB Kabupaten/Kota Jawa Tengah Tahun 2008-2012. JEJAK: Journal of Economics and Policy. Universitas Negeri Semarang.

Latif Adam dan Inne Dwistuti. (2015). Membangun Poros Maritim Melalui Pelabuhan. Jurnal Masyarakat Indonesia Lembaga IImu pengetahuan Indonesia. Vol.41, No.02

Sudarmo, S.T. (2012). Memberdayakan Kembali Manajemen Pelabuhan di Indonesia. Jurnal Prakarsa, Vol.10, No.01, hal 4-8 